\title{
The banding in serpentinites and its influence on character of talc-magnesite and magnesite mineralization (natural and experimental data)
}

\author{
V.V. NASEDKIN ${ }^{1}$; V. K. MARKOV ${ }^{2}$; N. M. BOEVA ${ }^{3}$; V.K. KRUPENIN ${ }^{4}$ \\ ${ }^{1,3,}$ Institute of Geology of Ore deposits, Petrography, Mineralogy and Geochemistry of Russian \\ Academy of Sciences, Moscow; nasdi@orc.ru \\ ${ }^{2}$ Institute of dynamics of geosphere of Russian Academy of Sciences, Moscow; \\ ${ }^{3}$ Institute of Geology and Geochemistry of Russian Academy of Sciences, Yekaterinburg;
}

(Received November 2002 Accepted December 2002)

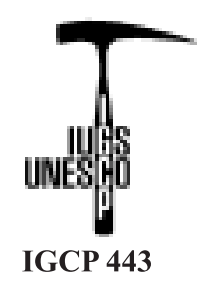

\begin{abstract}
The geological setting of some banded talc-magnesite ores and magnesites was studied in the field (Urals, Russia; Finland, East Iran). Talc-magnesite and magnesite ores occur in ultramafic rocks. Experimental methods were used in order to determine the influence of physico-mechanical parameters on the formation of banded structures in talc-magnesite rocks and magnesites. Experiments were carried out with axial compression up to $10 \mathrm{kbar}$ and confining pressure 2, 4, 6 and 8 kbars at room temperature.

The samples were chemically analyzed using a Philips Analytical PW 2400 authomatic XRF Spectrometer and a scanning electron microscope (SEM).

Some analyses were made with a "Camebax SX-50" electron microprobe, using an accelerating voltage of 20 kilovolts for all elements with a sample current of 20 nanoamps. X-ray method for phase identification was used. Structure peculiarities of rocks prior to the experiment and after were studied by optical methods in polished sections and thin sections.

It was shown, that banding in talc-magnesite stone and magnesites are inherited from banded serpentinites and can affect on distribution and composition rock-forming minerals.
\end{abstract}

Key words: magnesite, banding, talc-magnesite stone, ultrabasite, physico-mechanical properties, confining and axial pressure

\section{Introduction}

The banded structures are widely spread among serpentinous ultramafic rocks, serpentinites and often in talc-magnesite rocks and sometimes magnesites, spatially connected with serpentinites (Ogorodnikov et al. 2000; Nasedkin et al. 2001; Niemela 2001).

It is interesting, that banded structures are exhibited in variable degrees, practically, almost in all varieties of talc-magnesite stones. The relatively massive talcmagnesite stones or soapstones near contact with serpentinites usually give place to the banded varieties. We can speculate that schistose structure of talcmagnesite stone is inherited from the banded structure of serpentinites. This conclusion is confirmed by relationships between rock-forming minerals.
The processes of formation of talcites, magnesite, talc + magnesite association in ultramafic rocks and, in particular, serpentinites have many general peculiarities. The first, talc and magnesite in many cases replace serpentine. It is characteristic that serpentinization precedes formation of known minerals. Second, talc-magnesite rocks, talcites and in some cases magnesites have banded structure. The formation of banding took place after serpentization but before formation of main minerals (talc, magnesite). It is typical, that peculiarities of banding determinate mineral composition of ores, methods of processing and basic applications.

We made an attempt to simulate the schist formation in massive serpentinite, using experimental methods (Nasedkin \& Markov 2000). 


\section{Geological Setting}

Ultrabasite bodies are usually located along large faults and form ophiolitic belts. Magnesite, talc and talcmagnesite deposits occur in serpentinites and other ultrabasic rocks of these belts.

In the Urals there are more than 40 deposits of magnesite, talc-magnesite and talc ores. These deposits are located in the Ural ophiolitic belt expanding nearly $1,500 \mathrm{~km}$ from south to north. In this paper we will consider only those deposits where the banded structures are present. The Ural belt contains more than 20 deposits and occurrences of this type. Among the largest of them (from south to north) are the Chernigovskoe, Kulahninskoe, Kochnevskoe, Sirostanskoe and Shabrovskoe deposits (Fig.1).

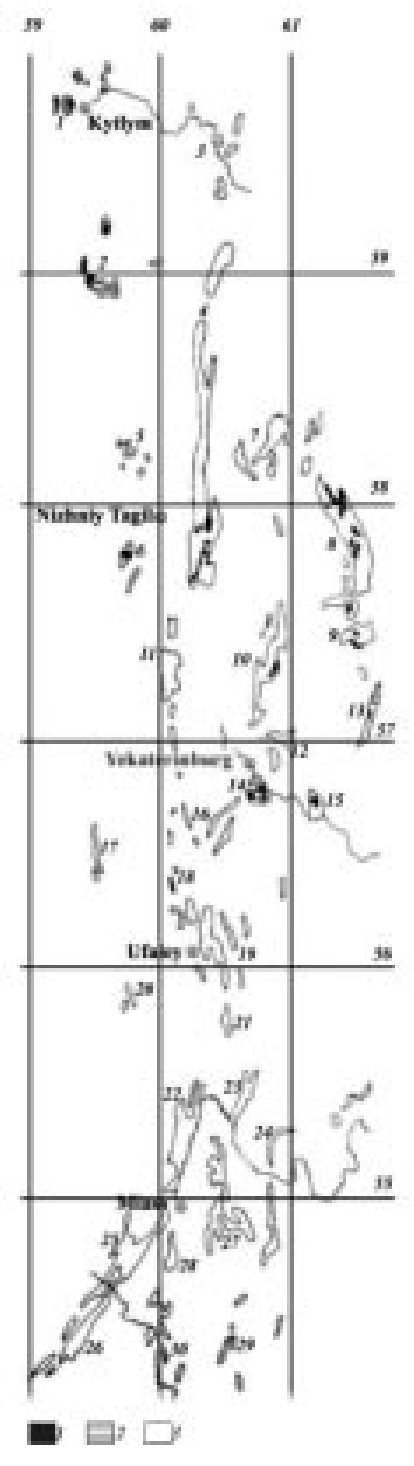

Fig.1. Distribution of ultramafic rocks and serpeninites in Urals (from I.A.Malachov)

1 - dunite, 2 - pyroxenite , 3 serpentinite.

Figures on map: 1 - Kitlim, 2 Kachkanar, 3 - Lobva, 4 Krasnouralsk, 5 - Barancha, 6 Nizhnetagilsky, 7 - Saldinsky, 8 - Alapaevsky, 9 - Rezhevsky, 10 - Pervomaisky, 11 Verchneivinsky, 12 Berezovsky,13 - Bazhenovsky, 14 - Uktus, 15 - Kluchevskoi, 16 -Sisertsky (Shabrovskoe deposit), 17 - Bardimsky, 18 Omutninsky, 19 - Ufaleisky, 20 Suroyam, 21 - Kischtim, 22 Karabash, 23 - Argazin, 24 Techensky, 25 - Atlyan, 26 Nuraly, 27 - Chebarcul, 28 - Mt. Listvyannaya (Kulachninskoe and Kochnevskoe deposits), 29 - Koelga, 30 - Uisky
The Shabrovskoe deposit is located in the Sverdlovskaya province, $20 \mathrm{~km}$ south from Ekaterinburg. The deposit region consists of metamorphosed primary sedimentary rocks (siliceous slates, quartzites, marbled limestones). Talc-magnesite stone forms two lenses - the "Old" lens and the "New" one. The "Old" lens has a steep dip; its length is $2 \mathrm{~km}$ and its thickness is about $50-350 \mathrm{~m}$. This lens is explored to the depth of $200 \mathrm{~m}$ and is exploited on the depth of $50 \mathrm{~m}$. The "New" lens has the following sizes: lengh $1.2 \mathrm{~km}$, thickness $-300 \mathrm{~m}$. Serpentinites present as relicts between talc-magnesite rocks. Talc-magnesite rocks and serpentinites near contact with country rocks have banded structure (Tatarinov 1969; Ogorodnikov et al. 2000).

Most authors that studied the Shabrovskoe deposit, are of the opinion that this deposit was formed into 2 stages. During the first stage, peridotites were transformed into serpentites as a result of autometamorphism. In the second stage, the hydrothermal solutions, associated with the granitic intrusion, transformed serpentinites into talcmagnesite rocks.

The Sirostanskoe deposit $(250 \mathrm{~km}$ south of Ekaterinburg) is similar in geological structure to Shabrovskoe deposit. Talc-carbonate rocks occur in the hanging wall of the serpentinite body. The main dissimilarity from Shabrovskoe deposit is the high degree of schistosity of talc-magnesite stone. This structural feature of talc-magnesite rock decreases the commercial significance of Sirostanskoe deposit as a source of dimension stone.

The similar talc-magnesite deposits (Kulachninskoe and Kochnevskoe) are known in the South Urals, 50 $\mathrm{km}$ south of Miass City with resources 3,5 and 0,6 Mt correspondingly.

Talc-magnesite deposits, associated with ultrabasic rocks are described all over the world (Japan, India, Egypt, Finland and other countries; Hirano \& Togashi 2001, Mandour \& Elmaatty 2001, Prasannakumar \& Kumar 2001).

The talc-magnesite deposits of Finland are situated in two zones: Archean greenstone belt and Proterozoic schist belt (Niemela 2001). The significant part of these deposits occurs in serpentinites or is connected to serpentinites genetically. In most cases, talc-magnesite ores have banding, pronounced to different extents. One of these deposits, Kivikangas has zonal structure. The central part of body is presented by massive or reticulate 
NASEDKIN, V. V. et al. The banding in serpentinites and its influence on character of talc-magnesite and magnesite mineralization (natural and experimental data)

soapstone. The relatively massive talc-magnesite stone grades to serpentinite at its western margin. The southern and eastern parts of body are weakly banded and zones in contact with the wall rocks in particular consist of banded soapstone.

The banded structures are characteristic for some magnesite deposits. For example, the majority of magnesite deposits of East Iran are presented by massive ores of the infiltration type, however there are banded ores near the contact with the serpentinites. In this case we consider the formation of banded magnesite as a first stage of magnesite-formation in serpentinites (Nasedkin et al. 2001).

The banded structures are typical not only for talcites, magnesites and talc-magnesite rocks but also for asbestos, chromite deposits associated with ultramaphites.

\section{Description of natural banded structures in talc - magnesite stone and magnesite}

Four samples were taken for investigation: one talcmagnesite stone from Shabrovskoe deposit (sample 20/ 82); one from Kivikangas deposit, Finland (s. 4/02); one from Nunnanlahti (s. 9/02); one magnesite rock from Tek-Sijo, East Iran (s. 2/01).

The talc-magnesite stone of Shabrovskoe deposit (sample 20/82). The sample was taken inform open-pit mine from the north-eastern part of ore body, from the so-called "Old" lens near the contact with serpentinite. Talc-carbonate rock has medium-flake banded structure. Carbonate (magnesite-breunerite, $8-12 \% \mathrm{FeCO}_{3}$ ) is as lens-liked aggregate. Talc, serpentine and chlorite are as fine-grained flakes. Talc replaces serpentine and chlorite (Table 1).

The talc-magnesite stone of Kivikangas deposit (sample 4/02). The sample is taken from the eastern part of ore body in the zone of contact with the country rocks. This zone consists of banded talc-magnesite ore or "soapstone." The rock has grey color and coarse-banded structure. Mineral composition includes magnesite, magnetite, talc, serpentine and chlorite. Magnesiteoccurs mainly as porphyroblasts $0.05-1 \mathrm{~mm}$ in size. Each porphyroblast can be represented as a lensshaped aggregate consisting of several nearly located grains, the grains decrease in size from the center to periphery of the lens. This position of grains gives the impression that large magnesite porphyroblasts were
Table 1: Mineral composition of examined rocks, wt.\%

\begin{tabular}{|l|c|c|c|c|c|}
\hline \multirow{2}{*}{ Mineral } & \multicolumn{5}{|c|}{ Samples } \\
\cline { 2 - 6 } & 1 & 2 & 3 & 4 & 5 \\
\hline Talc & 49 & 41 & 40,9 & trace & trace \\
\hline Breunnerite & 34 & 42 & 45,95 & 6 & 10 \\
\hline Magnesite & - & - & - & 22 & 50 \\
\hline Serpentine & 9 & 5 & 5 & no & 5 \\
\hline Chlorite & 4 & 6 & 3,5 & $-“-$ & - \\
\hline Cerolite & & & & 50 & 5 \\
\hline Magnetite & 4 & 4 & 4,2 & - & - \\
\hline Chromite & - & - & 0,18 & 3 & trace \\
\hline Pyrite & Trace & - & 0,2 & - & - \\
\hline Arsenopyrite & - & - & & 4 & 3 \\
\hline Dolomite & - & 2 & & 5 & 20 \\
\hline Siderite & - & - & & 5 & - \\
\hline Rutile & Trace & trace & & & - \\
\hline $\begin{array}{l}\text { Amorphous } \\
\text { SO } 2\end{array}$ & - & - & - & 6 & 7 \\
\hline Total & 100 & & 100 & 100 & 100 \\
\hline
\end{tabular}

1-Kivicangas $<$ s.4/02; 2- Nunnanlahti s.9/02;3- Shabrovskoe deposit, s.20/82; 4-5-Tek-Sijo, East Iran, 2/01 (4 - part of 2/ 01sample demonstrated on Fig 2,c; 5 - part the same sample shown on Fig. 2,d)

crushed and separated along plastic mineral plane slippage, represented mainly by such minerals as talc and serpentine (Fig. 2a). The magnetite grains are usually associated with magnesite porphyroblasts.

The talc-magnesite stone of Nunnanlahti (sample 9/02). Talc-magnesite stone is middle-flaked and schistose. Magnesite forms porphyroblasts up to 0.5 $10 \mathrm{~mm}$. Talc, serpentine and chlorite are as flakes flowing around magnesite porphyroblasts. Magnetite is a concentrate near magnesites (Fig. 2b).

Banded magnesite from Tek-Sijo deposit (sample 2/ 01). The colour - grey with green nuance banded structure is characteristic for magnesite. Thin parallel cracks are oriented along banding of rock. In one case these cracks are mainly filled with magnesite and cerolite (Fig. 2c), in other one - with clear magnesite, Fe-magnesite, dolomite, opal. Opal usually contains admixture of serpentine flakes and the finest inclusions of arsenopyrite and hydrogoethite (Fig. 2d). 


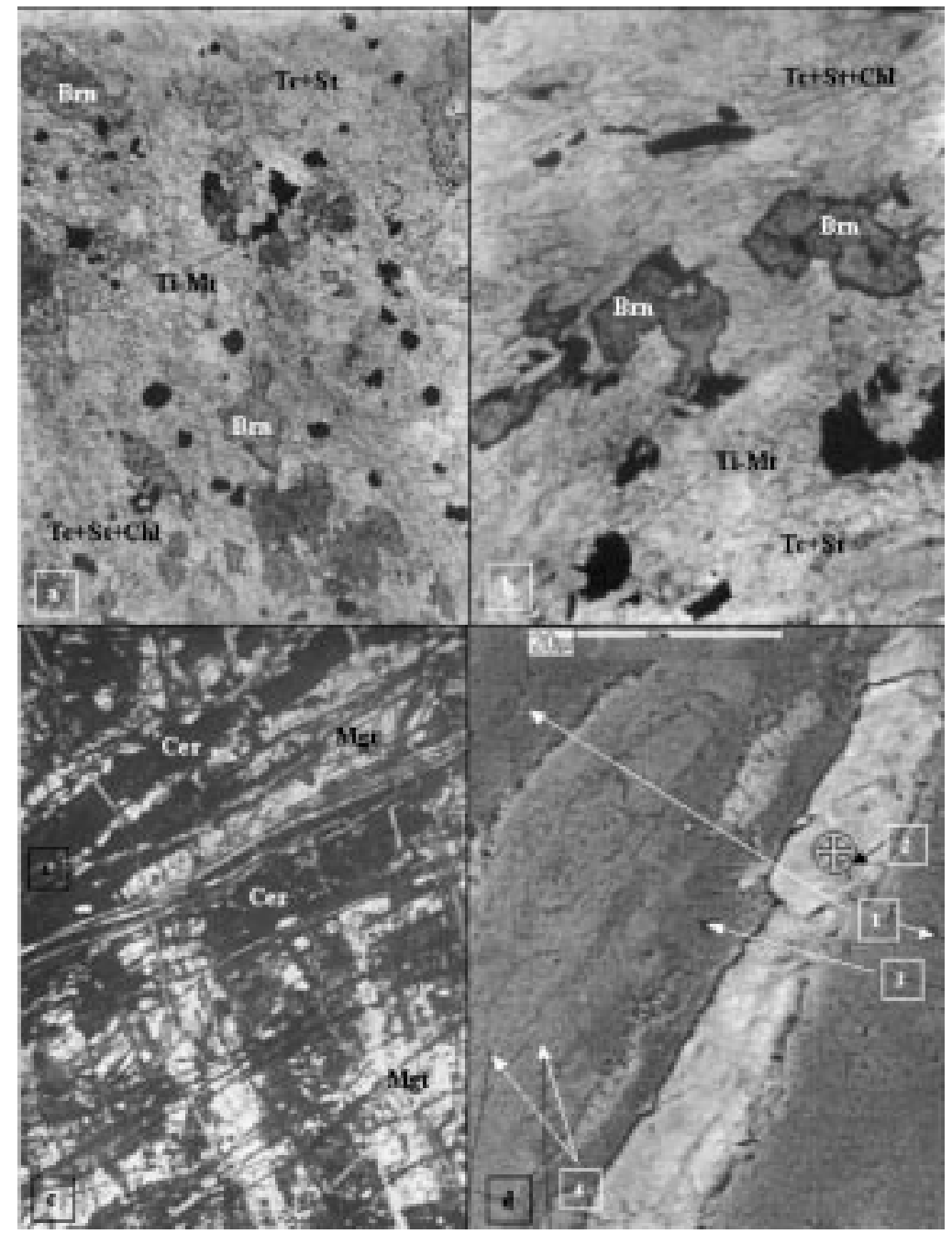

Fig. 2. The varieties of talc-magnesite rocks and magnesites.

a - The breunnerite porphyroblasts (Brn) in talc (Tc) -chlorite (Chl)-serpentine (St) aggregate, magn. 23, plane polarized light. Kavikangas deposit, sample 4/02. b- The breunnerite porphyroblasts (Brn) in talc (Tc)-chlorite $(\mathrm{Chl})-$ serpentine $(\mathrm{St})$ aggregate, magn. 30, plane polarized light. Nunnanlahti deposit, sample 9/02;

$\mathrm{c}$ - The banded magnesite ore, light - magnesite, dark - cerolite, opal, magn. 20, plane polarized light, Tek-Sijo deposit, sample 2/01.

d - detail of sample 2/01 (SEM), 1- magnesite, 2 - cerolite with finest inclusions arsenopyrite, 3 - Fe-magnesite, 4 - dolomite (on Table 2: 4, 5, 6, 7-correspondingly)

\section{Banding as result of experiment}

\section{Description of samples}

Three samples were taken for experiment: 1) pyroxenite, 2) dunite), 3) serpentinous peridotite.

The pyroxenite consists of the following minerals (vol. \%): diopside - 50, hypersthene - 20, serpentine of the antigorite type -30 .
The dunite (vol. \%): olivine $\left(8 \% \mathrm{Fe}_{2} \mathrm{SiO}_{4}\right)-36$, chrome-spinelid - 6 , titanomagnetite -3 , serpentine (antigorite) -55 .

Serpentinous peridotite (vol. \%): olivine $\left(10 \% \mathrm{Fe}_{2} \mathrm{SiO}_{4}\right)$ - 20, orthopyroxene -10 , serpentine (antigorite) -55 .

\section{Apparatus and method of experiment}

We made an attempt to simulate the schist formation 
NASEDKIN, V. V. et al. The banding in serpentinites and its influence on character of talc-magnesite and magnesite mineralization (natural and experimental data)

of the serpentinite. Special experiments were carried out at axial compression up to $10 \mathrm{kbar}$ and confining pressure 2, 4, 6 and 8 kbars. The experiments were carried out at room temperature.

The apparatus for study of rock physico-mechanical properties consists of two parts: an apparatus for the confining pressure and one for axial compression (Fig. 3).

The high pressure is produced with the help of the multiplicator. Pressure-transfer medium is presented by mixture of $60 \%$ glycerine and $40 \%$ ethyleneglycol. The pressure is measured by a spring manometer. The accuracy of measurement is \pm 1 kbar. The hydraulic tightener (4) produces additionally a one-axial force.

The special arrangement for the creating of main oneaxial compression (Fig. 3b) is placed in the working chamber (2) of the cylinder container (1) (Fig 3a). The

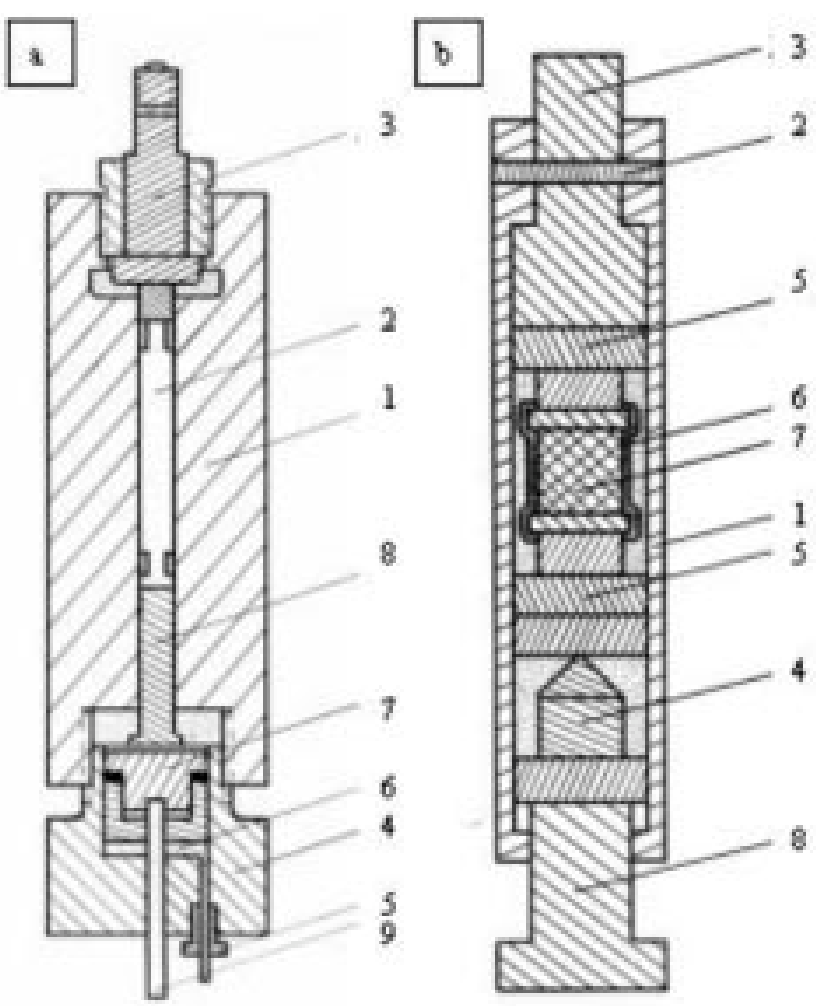

Fig. 3. Apparatus for study of rock physico-mechanical properties. a - apparatus for the comprehensive pressure (1- cylinder container, 2 - operation volume, 3- piping for liquid which produces pressure, 4 - hydraulic tightener to produce additional pressure, 5 - pipe for liquid, 6 - operation volume 2, 7- piston (plunger), 8 - rod to produce axis pressure). $\mathrm{b}$ - device for axial compression including following machine parts: 1 - cylinder with longitudal windows for charging of sample, 2-3 - rods, 4 - steel crusher to determine force of compression, 5 - supporting discs, 6 - rubber casing which preserves sample from liquid gearing pressure, 7 - sample, 8 - set screw. steel crusher (4, Fig. 3b) is dedicated for measurement of compression stress. The maximum stress acting on the sample in the course of the experiment is determined by the degree of crushing of the steel crusher. The function between the value of the crushing and the one of the force is determined on the basis of independent calibrations.

The experiments were carried out on cylindrical samples cut from massive rock. Size of samples: $d=6 \mathrm{~mm}, \mathrm{~h}=6$ $\mathrm{mm}$. The measured parameters in the experiments: confining hydrostatic pressure $\mathrm{P}$, residual deformation $\delta$, cross-sectional area $S$, maximal axial loading $F$.

Primary data presented as dependent between force $\mathrm{F}$ and residual deformation $\delta$, when different confining pressures $\mathrm{P}$ take place. It makes possible by means of values extrapolation $\mathrm{F}, \mathrm{P}, \delta$ on value of $\sigma=0$ to get value of loading F', which corresponds to the beginning of an irreversible deformation on given pressure. Suitable value of stress $\sigma^{\star}=F^{\prime} / S$ represents important strength characteristic of the rock - "boundary of rock flowage" (Nasedkin \& Markov 2000).

\section{Results of experiments}

Relation between axial loading and residual deformation (Fig. 4a-c). The experimental data for the pyroxenite, dunite and serpentinite are presented as coordinates: residual deformation $\delta$ - axial loading F in Fig. $4 \mathrm{a}, \mathrm{b}, \mathrm{c}$ correspondingly. As seen in Figures, dependences $\delta$ - F have correlative character. The lines of regression are obtained by the method of lowest square.

As is seen from the position of experimental points at different values of axial loading, the positive slope of regressive line demonstrates the strengthening of rocks in the process of deformation. The strength of rocks increases along with the hydrostatic pressure. The displacement of these lines takes place in the direction of the increasing loads.

Dependence of "boundary of rock flowage" on pressure and relation between plastic and brittle minerals (Fig. 5). The value of "boundary of rock flowage" increases along with the comprehensive hydrostatic pressure $\mathrm{P}$.

The strength of rock decreases with the increase of serpentine in the rock. Mineral compositions of rocks are given as histograms, which illustrate the relationship between plastic serpentine and brittle olivine and pyroxene. The increase of serpentine in rock from 30 to $60 \%$ considerably decreases the "boundary of rock flowage". 

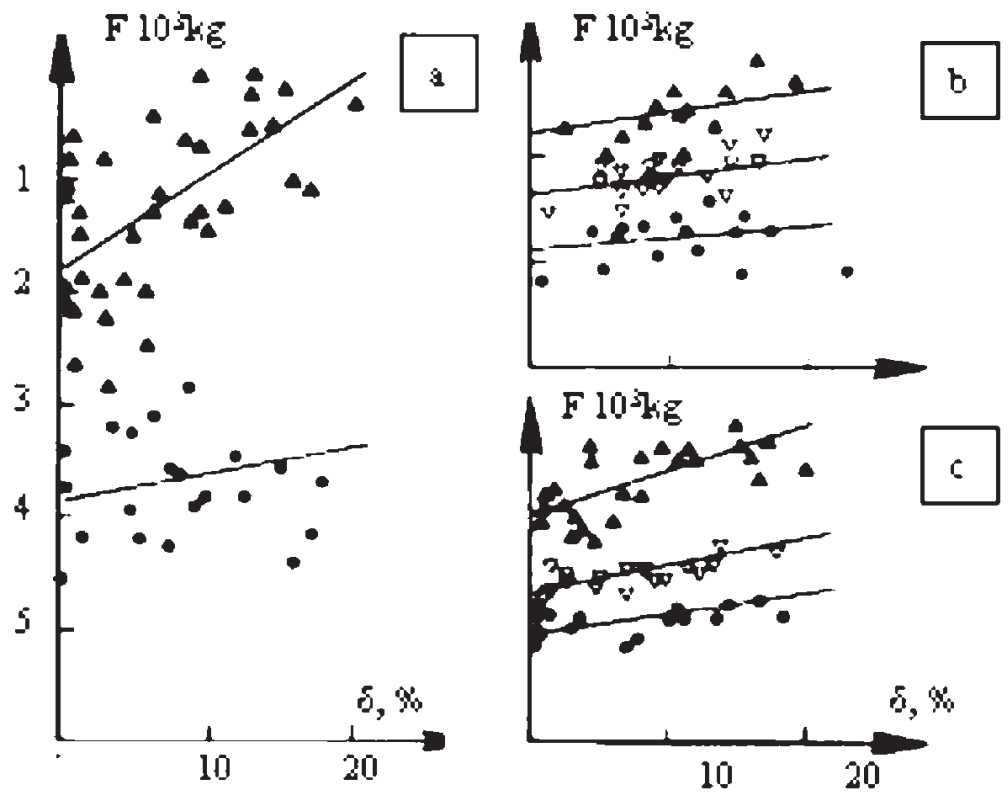

Fig. 4. Relation between axial loading and residual deformation for pyroxenite (a), olivinite (b) and serpentinous peridotite (c). Triangles and circles on diagrams - experimental points.

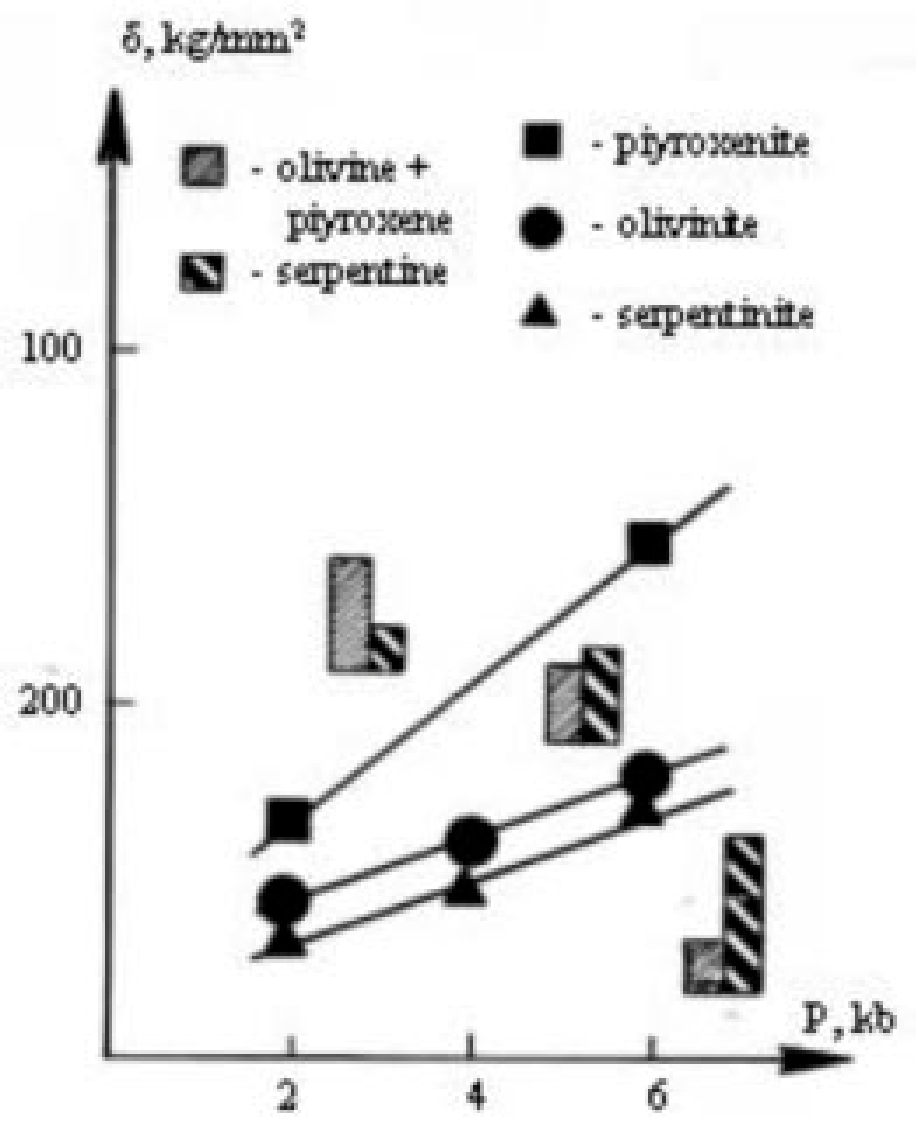

Fig. 5. Dependence of "boundary of rock flowage" on pressure and relation between plastic and brittle minerals. Explanations see on diagram. 
Evolution of deformation zones. Mechanism of deformation of serpentinous ultramafic rocks is characterized by interaction between brittle olivine and pyroxene and secondary plastic serpentine.

The sample, consisting of olivine (20\%), pyroxene (10\%) and serpentine (70 \%), was taken for investigation. Serpentinization appeared as replacement of olivine and pyroxene with serpentine. At the first stage of replacement the serpentine is formed around grains of olivine and pyroxene.

During the successive replacement, (the main stage) veinlets of serpentine are formed along fractures inside of brittle minerals (olivine, pyroxene). As a result of such replacement a looped structure is formed (Fig. 6a). Deformation of this rock originates as gliding of brittle minerals along serpentine intercalations and its additional breakdown. Origin of oriented structure is a characteristic feature of the deformation process of serpentinous ultramafic rocks.

Such oriented structure was obtained as a result of experiment. Elongated serpentine intercalations (light bands) and rows of crushed olivine crystals are distinctly seen in Fig. 6 b-c.

Origin of oriented structure is as a rule connected to zones of shifting stress.

The polished sections (to the left) and thin sections (to the right) of the samples, deformed at different residual axial deformation and by confining pressure of $4 \mathrm{kbar}$, are presented in the picture (Fig. 7a-d). The zones of structure formation are clearly seen in polished sections as light bands. The deformation zone with residual deformation of $5 \%$ is seen as a light band extended in diagonal directions in the zone of maximal tangent shears. The cross-liked zone is forming at a higher degree of deformation, about $7 \%$. Then, the crushing zone at residual deformation of $10 \%$ is developed from the centre to edge of the sample. As it was noted earlier the main mechanism of deformation is found in the relationship between brittle olivine and pyroxene and plastic serpentinite.

\section{Discussion of results}

Many deposits of industrial minerals (talc-magnesite stone, talcites, magnesite, asbestos), genetically and spatially connected with ultramafic rocks, occur in banded serpentinites.
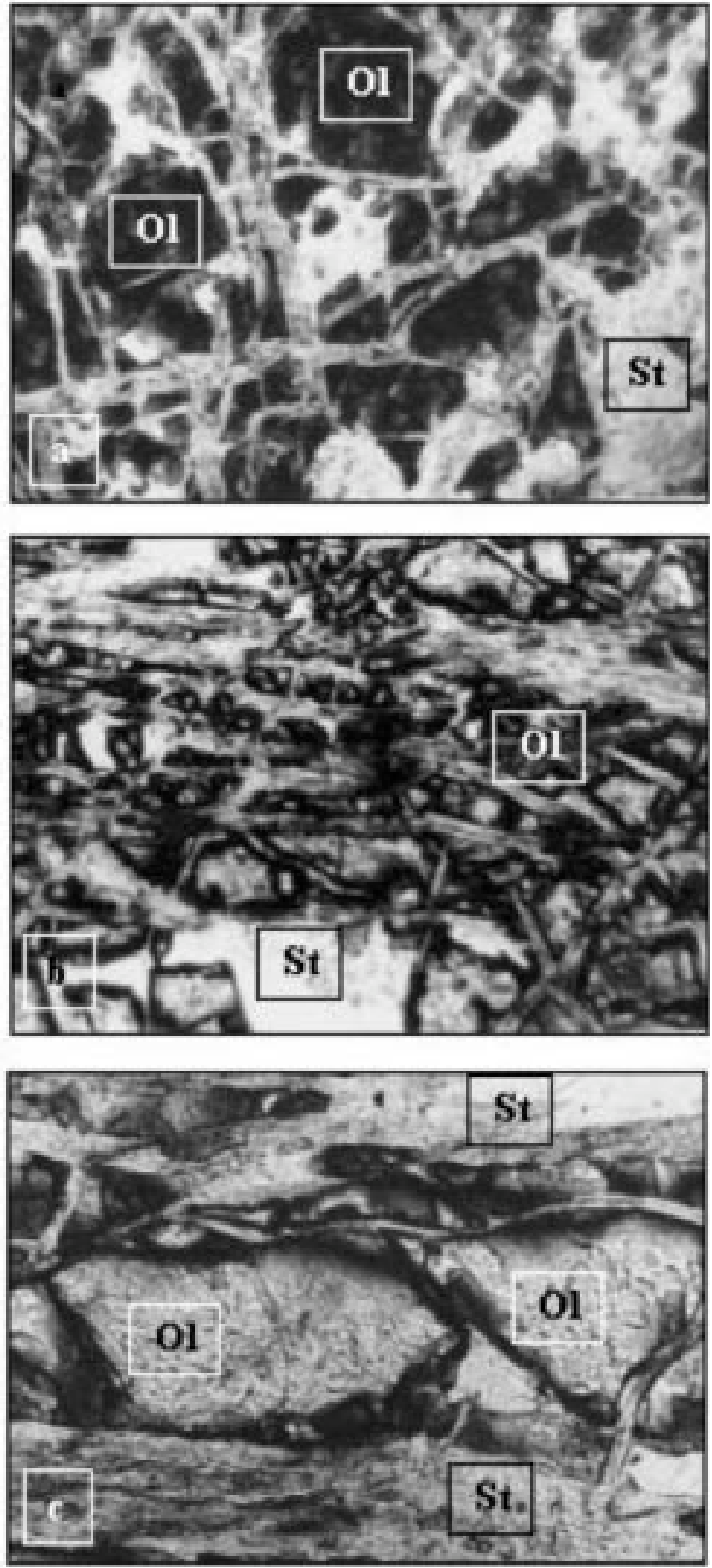

Fig. 6. The deformation of serpentinous peridotite and formation of banding. a - original sample with looped structure, $\mathrm{Ol}$ - olivine, $\mathrm{St}$ serpentine (antigorite), magn. 40, crossed polarized light, $\mathrm{b}$ - initial stage of deformation, appearance of oriented structure, magn. 40, plane polarized light, $\mathrm{c}$ - intensive deformation, boundinage of olivine grains, magn. 140, plane polarized light. 

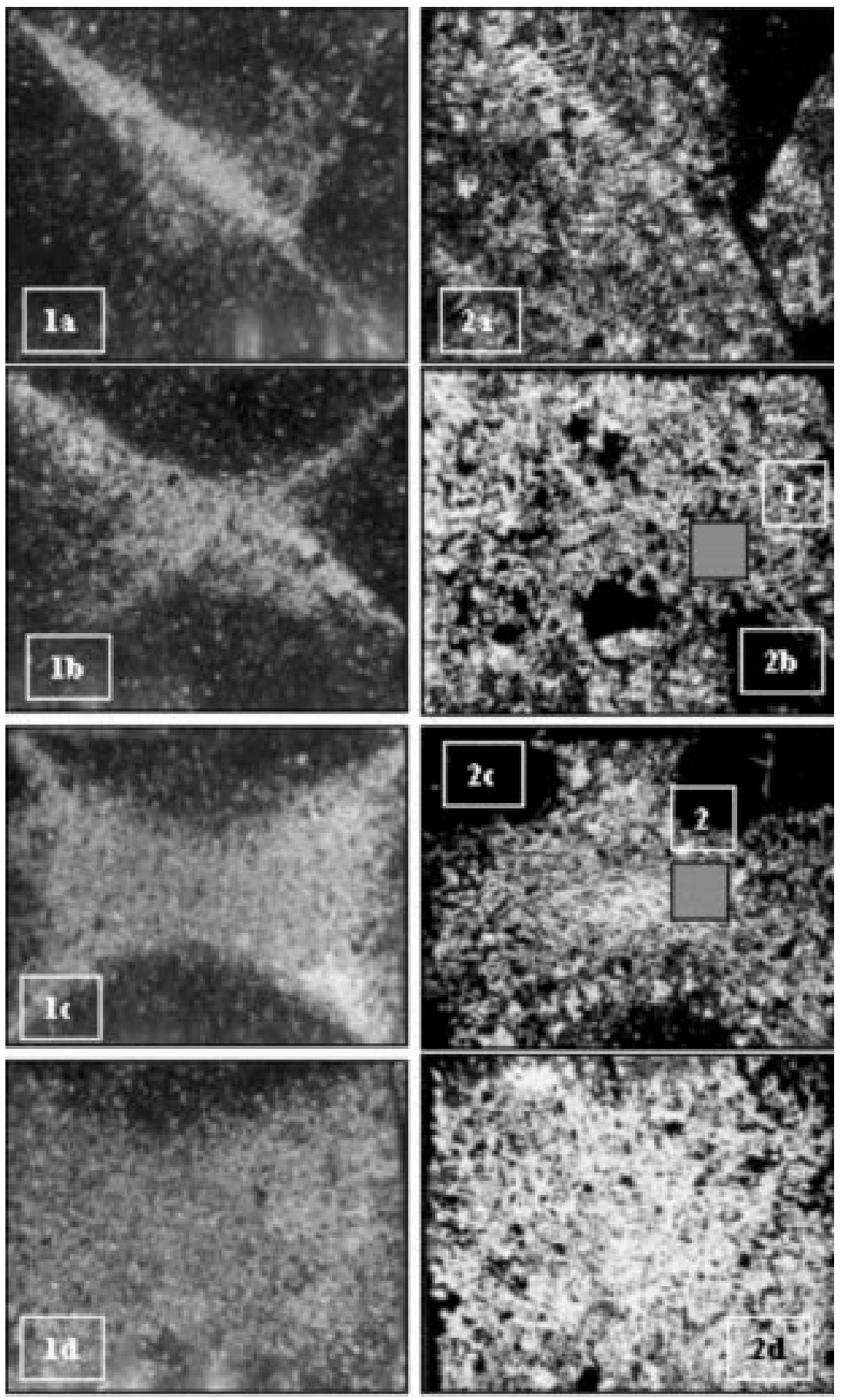

Fig. 7. The development of deformations in serpentinous peridotite (to the left polished section, to the right thin section with crossed polarized light, magn. 8): a - generation of diagonal shear fractures, $\mathrm{b}$ - development of diagonal shear fractures, appearance zone of destruction on crossing of diagonal fractures, 1- region of thin section demonstrated in Fig. 6b, c - development of central destruction zone and subsequent orientation of mineral particles (2 - region of thin section demonstrated in Fig. 6c); d final stage of destruction of sample 
NASEDKIN, V. V. et al. The banding in serpentinites and its influence on character of talc-magnesite and magnesite mineralization (natural and experimental data)

Most of the investigators reported, that the ultramafic rock is subjected to complex transformations prior to formation of talc and magnesite. In the Urals the signs of hot contacts between ultramafic massifs and country rocks are absent. So we believe, that massifs of ultramafic rocks were lifted as blocks from the mantle along faults and, after that, they were subjected to serpentinization. According to some authors (Rusin 2002) the inflow of water and the serpentinite formation can take place on different depths from 0.5 to $5 \mathrm{~km}(0.1-2.5 \mathrm{kbar})$ and in the temperature range from 100 to $500{ }^{\circ} \mathrm{C}$.

Under the effect of stress the formation of banding can originate in the course of total or partial serpentization or after the serpentization. In these conditions there can be originated specific stress minerals (serpophyte a.o.), thin jointing and banded structures. As it was shown previously, many of industrial minerals are connected to this phenomenon.

The consanguinity between the system of thin factures developed in parallel banding of serpentinites and asbestos-forming rocks was reported by many authors (Lodochnicov 1933, Merenkov 1958). The authors of this paper studied banding structures that characterized both endogenetic and exogenetic conditions.

The endogenetic mineralizations (talc + magnesite association). Magnesite in Kivikangas, Shabrovskoe and other deposits has the form of porphyroblasts. These porphyroblasts are intensively fractured, crushed and have migrated along planes of linear deformation (flowage). Interporphyroblasts space is occupied with oriented flakes of plastic minerals (talc, serpentine and chlorite).

As a result of the experiment, the analogous relationships between minerals were obtained, but instead of magnesite, the olivine and pyroxene were present. The comparison of the natural and experimental data gives possibility to substantiate the following successions of mineral formation.

In the first stage, a block of ultramafic rock can be uplifted to the upper horizon of the earth's crust. In the second stage, metamorphism of the ultramafic rocks takes place in the presence of $\mathrm{H}_{2} \mathrm{O}$ and $\mathrm{CO}_{2}$ If $\mathrm{X}_{\mathrm{H} 2 \mathrm{O}}$ >> $\mathrm{X}_{\mathrm{CO} 2}$ the reaction is possible (Winkler 1979) in the following way:

$$
\underset{\text { Forsterite }}{2 \mathrm{M}_{2} \mathrm{SiO}_{4}}+3 \mathrm{H}_{2} \mathrm{O} \rightarrow \underset{\text { Serpentine }}{\mathrm{Mg}_{3} \mathrm{Si}_{2} \mathrm{O}_{5}(\mathrm{OH})_{4}}+\underset{\text { Brucite }}{\mathrm{Mg}(\mathrm{OH})_{2}}
$$


NASEDKIN, V. V. et al. The banding in serpentinites and its influence on character of talc-magnesite and magnesite mineralization (natural and experimental data)

\section{References}

Hirano, H. \& Togashi, Y. 2001: Talc deposits in Japan: a review. Mineralia Slovaca. 33, 595-598

Lodochnikov, V.N. 1933: Serpentines and serpentinites and petrographycal problems connected with them. Problems of Soviet geology. 5, 82-88

Mandour, M.A. \& Elmaatty, M.A. 2001:Egyptian magnesite and talc deposits: a brief review. Mineralia Slovaca. 33, 587-590

Merenkov, B.Ya., 1959: Genesis of chrysotile-asbestos. Moscow, 135

Nasedkin ,V.V.\& Markov ,V.K.: 2000. Some features of microdestruction evalution in rocks by high pressure. In: V.N. Strachov (Ed.), Phisical properties of rocks by high pressures.

Institute of Physics of Earth. Moscow. 39-41.

Nasedkin, V.V. , Krupenin, M.T.,. Safonov, Yu. G , Boeva, N.M., Efremova, S.V.and Shevelev, A.I. 2001. The comparison of amorphous (cryptocrystalline) and crystalline magnesites. Mineralia Slovaca. 33. 567-574
Niemela, M. Talc-magnesite deposits in Finland. 2001.Mineralia Slovaca. 33. 561-566

Ogorodnikov, V.N., Sazonov, V.N., Polenov, Yu. A. \& Grigoriev, V.V. 2000. The Shabrovskii mainfield (Middle Urals) Ekaterinburg. Uralian division of R.A.S. 80

Rusin, I.A. 2002. Mineral association of metabasites of lherzolite complexes and problem of exhumation.2002: In : Yushkin N.P. (Ed). New ideas and conceptions in mineralogy. Syctyvkar, 140-141

Prasannakumar V. \& Kumar S.N. 2001. Magnesite and talc- the Indian scenario, Mineralia Slovaca. 33, 599-602.

Tatarinov P.M. ( Ed),1969: Non-metallic raw materials.Nedra. Moscow. 470

Winkler, H.G. 1979. Petrogenesis of metamorphic rocks. Nedra. Moscow. 326. 